\title{
CULTURED ADULT RAT JEJUNAL EXPLANTS AS A MODEL FOR STUDYING REGULATION OF CYP3A
}

\author{
Phyllissa Schmiedlin-Ren, Patrick E. Benedict, William O. Dobbins III, \\ Mita Ghosh, Juseph C. Kolars and Paul B. Watkins" \\ Departments of Internal Medicine, University of Michigan Medical Center and Veterans \\ Administration Medical Center, Ann Arbor, MI 48109, U.S.A.
}

(Received 26 January 1993; accepted 23 April 1993)

\begin{abstract}
Enzymes within the CYP3A subfamily are major Phase I drug-metabolizing enzymes present in hepatocytes and small bowel enterocytes. These enzymes are highly inducible in the liver by many structurally diverse compounds, including a number of commonly used medications. Studies indicate that CYP3A enzymes present in small bowel enterocytes are also inducible. However, the regulation of CYP3A enzymes in this tissue has not been well characterized, in part because in vivo studies are difficult, especially in humans. Our goal was to develop an in vitro model to study the regulation of CYP3A in enterocytes. To this end, we defined culture conditions under which adult rat jejunal explants maintained viable appearing villi for $21 \mathrm{hr}$. When dexamethasone, the prototypical inducer of CYP3A1 in rat hepatocytes, was added to the culture medium, there was a time-dependent induction of CYP3A1 mRNA and CYP3A protein in explant enterocytes which was essentially indistinguishable from the time course of induction of CYP3A1 mRNA and protein in enterocytes in vivo. This effect of dexamethasone appeared to be specific since dexamethasone had no consistent effect on the explant concentration of another enterocyte specific mRNA, intestinal fatty acid binding protein. Using this explant culture model, we found that CYP3A1 mRNA was also inducible by clotrimazole but we were unable to detect induction by rifampicin or troleandomycin. Our observations suggest that jejunal explants may provide an appropriate model for the study of the regulation of CYP3A and other drug-metabolizing enzymes.
\end{abstract}

The cytochromes P450 (P450s $\dagger$ ) are a gene superfamily of heme-containing enzymes responsible for the oxidative metabolism of xenobiotics, including many important medications (reviewed in Refs. 13). P450s are most abundant in the liver where their

* Corresponding author: Paul B. Watkins, M.D., University of Michigan Medical Center, Room A7119 University Hospital, 1500 East Medical Center Drive, Ann Arbor, MI 48109-0108. Tel. (313) 936-8080; FAX (313) 936-4024.

† Abbreviations: P450s, cytochromes P450; DEPC, diethylpyrocarbonate; IFABP, intestinal fatty acid binding protein; PBS, phosphate-buffered saline (137 mM NaCl) $\left.2.68 \mathrm{mM} \mathrm{KCl} / 8.1 \mathrm{mM} \mathrm{Na}_{2} \mathrm{HPO}_{4} / 1.47 \mathrm{mM} \mathrm{KH}_{2} \mathrm{PO}_{4}\right) ; \mathrm{PCR}$, polymerase chain reaction; and TAE, $0.04 \mathrm{M}$ Tris-acetate, 0.001 M EDTA, pH 8.0.

¥ Complimentary DNAs corresponding to two genes (CYP3A1 and CYP3A2) have been cloned and sequenced from a rat liver cDNA library [5]. It seems likely that additional CYP3A genes exist because approximately $90 \mathrm{~Kb}$ of rat genomic DNA hybridize with a CYP3A cDNA under low stringency conditions [5] and just $30 \mathrm{~kb}$ of this can be accounted for by the CYP3A1 gene (John Schuetz, personal communication, cited with permission). Moreover, three proteins that appear to belong to the CYP3A family have been purified from rat liver [6] and up to four distinct proteins immunochemically related to purified CYP3A proteins have been detected on immunoblots of liver microsomes $[7,8]$. In aggregate, these observations suggest that the $C Y P 3 A$ gene family is probably not large; $C Y P 3 A 1$, $C Y P 3 A 2$ and probably one or two additional unidentified genes are expressed in rat liver. In rat enterocytes, we have shown that the CYP3A protein(s) present in enterocytes obtained from untreated rats is unlikely to be the product(s) of the CYP3A1 or CYP3A2 genes and presumably reflects expression of the unidentified gene(s) [8]. regulation has been studied extensively. The P450s that have been implicated most frequently in the hepatic metabolism of xenobiotics belong to three families, each comprised of proteins that share greater than $40 \%$ amino acid sequence homology [4]. One family (termed CYP1) contains two highly homologous proteins that are inducible by $2,3,7,8-$ tetrachlorodibenzo- $p$-dioxin (TCDD) and some arylhydrocarbons. The second family (CYP2) is complex and includes the major phenobarbitalinducible P450s (CYP2B1 and CYP2B2) and the major ethanol-inducible P450 (CYP2E1).

We have been most interested in a group of enzymes within the third P450 family which share greater than $65 \%$ amino acid sequence homology and are termed the CYP3A $¥$ subfamily. In the liver, CYP3A enzymes are inducible by dexamethasone and for this reason CYP3A enzymes have been called the "glucocorticoid-inducible" P450s [7, 911]. However, CYP3A enzymes have been shown to also be inducible in the liver by many structurally diverse compounds, including a number of commonly used medications $[7,9-13]$. Cultured primary hepatocytes retain responsiveness to many CYP3A inducers and therefore provide a valid in vitro model for the study of CYP3A regulation [13-17]. The use of cultured hepatocytes has greatly facilitated the characterization of the regulation of hepatic CYP3A in a variety of mammals, including humans [13].

CYP3A enzymes are also abundant in rat and human enterocytes $[18,19]$. We have shown previously that when rats are treated with dexamethasone, there is induction of CYP3A protein and CYP3A1 mRNA in jejunal enterocytes $[18,20]$. 
We have also shown that the antibiotic rifampicin, which induces CYP3A enzymes in human liver, induces CYP3A protein and CYP3A4 mRNA in human small bowel enterocytes [19]. However, it is not known whether enterocytes respond to other inducers of liver CYP3A enzymes. This is likely to be a clinically important question because we have shown that in both rats and humans CYP3A within small bowel enterocytes can catalyze significant "first pass" metabolism of some orally administered medications $[20,21]$. Induction of enterocyte CYP3A enzymes results in increased "first pass" metabolism of orally administered substrates in rats and it seems likely that this is also the case in humans $[19,21-$ 23]. Induction of enterocyte CYP3A could therefore reduce the oral bioavailability of CYP3A substrates including dihydropyridine calcium channel antagonists [24], immunosuppressives [25], and dietary contaminants such as aflatoxin $B_{1}[26]$.

It would be difficult to study regulation of CYP3A enzymes in enterocytes in vivo, particularly in humans. It would obviously be desirable to have an in vitro model suitable for these studies. We here present data that suggest that cultured explants of jejunum may provide such a model.

\section{METHODS}

The animal studies performed were in compliance with NIH guidelines for the use and care of laboratory animals and were approved by the University Committee on Use and Care of Animals of the University of Michigan.

\section{In vivo studies}

Animals and treatments. Female Sprague--Dawley rats weighing $175-200 \mathrm{~g}$ were obtained from Charles River Laboratories (Portage, MI) and housed in wire-bottom cages. The animals had free access to tap water and standard laboratory chow until dexamethasone (Sigma Chemical Co., St. Louis, MO), $80 \mathrm{mg} / \mathrm{kg}$, was administered in $1 \mathrm{~mL}$ corn oil by intraperitoneal injection; then the food was removed but access to water continued ad lib.

Enterocyte isolation. Each rat was given light ether anesthesia prior to decapitation. A $20-\mathrm{cm}$ segment of jejunum beginning $2 \mathrm{~cm}$ distal to the ligament of Treitz was excised. Enterocytes were isolated from the jejunal segment by calcium chelation $[27,28]$. Light microscopy of tissue sections revealed that the enterocytes along the entire length of the villi, but not crypt cells, were harvested. Because of the relative instability of RNA, the method was modified when harvesting enterocytes for RNA isolation by using room temperature rather than $37^{\circ}$ solutions.

Microsome preparation. Microsomes were prepared from the harvested enterocytes by the calcium precipitation method of Bonkovsky et al. [28] with the modification that cell disruption was accomplished by sonication using a Sonifier Cell Disruptor (Heat Systems/Ultrasonics, Farmingdale, NY) at setting 100 for $10 \mathrm{sec}$.

Protein assay. The protein concentrations of the microsomal samples were measured by the method of Lowry as modified by Schacterle and Pollack [29].

Western immunoblots. Immunoblots were pre- pared as previously described [30]. CYP3A proteins were detected using a monoclonal antibody named 13-7-10 [31] at a concentration of $0.024 \mathrm{mg}$ protein/ $\mathrm{mL}$. This antibody recognizes CYP3A proteins present in rat liver and small bowel enterocytes $[18,30]$. (The 13-7-10 antibody was a gift from Dr. Pierre Kremers, Laboratoire de Chimie Medicale, Institut de Pathologie, Université de Liège, Liège, Belgium.)

$R N A$ isolation. After pelleting the enterocytes by centrifugation at $900 \mathrm{~g}$ at $4^{\circ}$ for $5 \mathrm{~min}$ and aspirating and discarding the Solution $B(2.7 \mathrm{mM} \mathrm{KCl} / 137 \mathrm{mM}$ $\mathrm{NaCl} / 1.47 \mathrm{mM} \mathrm{KH}_{2} \mathrm{PO}_{4} / 8.1 \mathrm{mM} \mathrm{Na} 2 \mathrm{HPO}_{4} / 1.5 \mathrm{mM}$ EDTA $/ 0.5 \mathrm{mM}$ dithiothreitol $/ 0.23 \mathrm{mM}$ phenylmethylsulfonyl fluoride) $[27,28]$, the cells were dispersed by vortexing in $10 \mathrm{mM}$ Tris- $\mathrm{HCl}(\mathrm{pH} 7.4)$ / $4 \mathrm{M}$ guanidine isothiocyanate [32]/2\% $N$-lauroylsarcosine (sodium salt)/1 M 2-mercaptoethanol and then stored at $-80^{\circ}$. At a convenient later time, each sample was thawed rapidly at $65^{\circ}$, drawn twice through a 23-gauge needle, layered over a $5.7 \mathrm{M}$ cesium chloride cushion [33], and then centrifuged at $32,000 \mathrm{rpm}$ overnight in a Beckman L8-70M ultracentrifuge (Beckman Instrument Co., Arlington Heights, IL) using an SW41 swinging bucket rotor. The resulting pellet was washed twice with absolute ethanol, then redissolved in diethylpyrocarbonate (DEPC)-treated water while heating to $60^{\circ}$ for $5 \mathrm{~min}$. A $1 / 10$ volume of $3 \mathrm{M}$ sodium acetate $(\mathrm{pH} 5.0)$ and 3 volumes of cold absolute ethanol were added and mixed, and the sample was placed at $-80^{\circ}$ for at least $1 \mathrm{hr}$. RNA was pelleted by centrifugation at $10,000 \mathrm{~g}$ at $4^{\circ}$ for $10 \mathrm{~min}$. The pellet was dried and then dissolved in DEPC-treated water. RNA concentrations were measured using absorbance at $260 \mathrm{~nm}$. The polymerase chain reaction was carried out as described below for in vitro studies.

\section{In vitro studies}

Animals. Female Sprague-Dawley rats (270$315 \mathrm{~g}$ ) were obtained from Charles River Laboratories and housed in wire-bottom cages. The animals had free access to tap water and standard laboratory chow.

Surgery. Each rat was given light ether anesthesia prior to decapitation. A segment of jejunum $\leqslant 20 \mathrm{~cm}$ in length was excised beginning $1 \mathrm{~cm}$ distal to the ligament of Treitz. The jejunal segment was placed immediately in a sterile petri dish on ice which contained 80\% CMRL Medium 1066/20\% F-12 (Ham) Nutrient Mixture that had been supplemented with glucose to a final concentration of $25 \mathrm{mM}$ and that had been equilibrated with $95 \% \mathrm{O}_{2} / 5 \% \mathrm{CO}_{2}$. A portion of this medium was used to gently flush debris from the lumen of the segment. Sterile scissors were used to cut open the jejunal segment lengthwise and, beginning just distal to the first $1 \mathrm{~cm}$ which was discarded, $2-3 \mathrm{~mm}$ wide full thickness strips (weighing approximately $40 \mathrm{mg}$ each) were cut off and placed in culture. As 0-hr specimens, one strip was placed in neutral buffered formalin and another in denaturing solution (4 M guanidine isothiocyanate/ $25 \mathrm{mM}$ sodium citrate $(\mathrm{pH} 7.0) / 0.5 \%(\mathrm{w} / \mathrm{v}) \mathrm{N}$ lauroylsarcosine) [34]. The latter strip was homogenized with a conical glass tissue grinder and 
stored at $-80^{\circ}$ pending further processing (see " $R N A$ isolation" below).

Culture conditions. The jejunal explants were cultured by the method of Browning and Trier [35] but using a different medium. In our hands, CMRL Medium 1066 (as used by Autrup et al. [36] for rat colon explant cultures) has been superior to Trowell's T8, L15, Medium 199, and Dulbecco's Modified Eagle Medium (DMEM), and equal or superior to RPMI 1640 in supporting the viability and maintaining the differentiation of adult rat jejunal enterocytes in explant cultures. We have found no benefit in adding HEPES (10 or $25 \mathrm{mM}$ ) or tricine (10 or $50 \mu \mathrm{M}$ ) buffers, $5 \mathrm{mM}$ galactose, $5 \mathrm{mM}$ pyruvate, $5 \mathrm{nM}$ ammonium vanadate, the oxygen carriers heptacosafluorotributylamine $(2 \%, 4 \%$, or $10 \%, \mathrm{v} / \mathrm{v}$ ) or perfluorotributylamine (as FC-43 Emulsion; Green Cross Corp., Osaka, Japan), or rat bile $(0.1 \%, 0.2 \%$, or $0.4 \%, \mathrm{v} / \mathrm{v})$ to the medium. For the experiments described, the culture medium was composed of 8 parts CMRL Medium 1066 (Gibco BRL, Grand Island, NY) + 2 parts F-12 (Ham) Nutrient Mixture (Gibco BRL), combined and then supplemented to the indicated final concentrations with the following: fetal bovine serum (Hyclone, Logan, UT), 10\%; glucose (Abbott Laboratories, North Chicago, IL), $25 \mathrm{mM}$; Lglutamine (Gibco BRL), $2 \mathrm{mM}$; ferrous sulfate (Sigma), $5 \mu \mathrm{M}$; sodium selenite (Sigma), $0.1 \mu \mathrm{M}$; 5aminolevulinic acid (Sigma), $100 \mu \mathrm{M}$; zinc sulfate (Sigma), $3 \mu \mathrm{M}$; menadione sodium bisulfite (Sigma), $145 \mathrm{nM}$; DL- $\alpha$-tocopherol (Gibco BRL), $45 \mathrm{nM}$; retinol acetate (Gibco BRL), $152 \mathrm{nM}$; sodium penicillin G (Gibco BRL), $100 \mathrm{U} / \mathrm{mL}$; and streptomycin sulfate (Gibco BRL), $100 \mu \mathrm{g} / \mathrm{mL}$. All components used to supplement the medium were of cell culture quality. We have found recently that discontinuing supplementation with retinol acetate may be associated with less enterocyte dedifferentiation.

Medium $(2.3 \mathrm{~mL})$ was placed in the inner well of a polystyrene organ culture dish (Falcon, Oxnard, CA). A sterile stainless steel screen was placed on the ledge of the inner well and was submerged in the upper medium. Sterile normal saline was placed in the outer well. The dishes were placed in an airtight jar that was gassed for $20 \mathrm{~min}$ with $95 \% \mathrm{O}_{2} /$ $5 \% \mathrm{CO}_{2}$ at $1700 \mathrm{cc} / \mathrm{min}$, theoretically providing nearly 14 volume exchanges of gas. The jar was then sealed and a minimum of 40 additional min was allowed to elapse so that the medium could equilibrate with the new atmosphere.

While the animal was being anesthetized, the culture dishes were removed from the jar and placed on ice. Surgery was performed as described above and each full thickness jejunal strip was placed villous side up on the stainless steel screen in an organ culture dish (one explant per dish). The explanted tissue was not fully submerged, but medium was observed to be drawn between and over the villi by capillary action. The cultures were maintained on ice until all were obtained. The dishes were then returned to the air-tight jar that was gassed for $20 \mathrm{~min}$ and sealed. The start of gassing occurred 15-20 min after decapitation of the rat and was considered $0 \mathrm{hr}$. The jar was placed on a rotating table at $40 \mathrm{rpm}$ in a $37^{\circ}$ incubator. The constant agitation produced by the rotating table appeared to minimize the adherence to the villi of sloughed enterocytes and generally improved the viability of the explants.

Treatments. Paired jejunal explants from a single rat were exposed throughout the 18 to 21 -hr culture period to dexamethasone (Sigma) or, in the final study, other compounds believed to induce CYP3A in hepatocytes [7, 10-13]: spironolactone (Sigma); phenobarbital (Spectrum Chemical Co., Gardena, CA); $\gamma$-chlordane (gift from the Velsicol Chemical Corp., Chicago, IL); troleandomycin ("triacetyloleandomycin"; gift from Pfizer Laboratories, Brooklyn, NY); rifampicin (Sigma); ketoconazole (Sigma; discontinued 10/91); clotrimazole (Sigma); or isosafrole (Aldrich Chemical Co., Milwaukee, WI). A $10^{-2} \mathrm{M}$ solution of each compound was prepared in dimethyl sulfoxide. Each solution was then diluted 1:1000 in culture medium, resulting in a final concentration of test compound of $10^{-5} \mathrm{M}$. This concentration has been used previously in primary cultures of rat hepatocytes when screening for induction of CYP3A enzymes $[14,16,37]$. Control cultures were exposed to vehicle alone (dimethyl sulfoxide) diluted $1: 1000$ in culture medium. At the end of the culture period, one explant from each pair was placed in neutral buffered formalin and the other was placed in denaturing solution [34], homogenized in a conical glass tissue grinder, and stored at $-80^{\circ}$ pending further processing (see "RNA isolation" below). For the studies examining the time course of response to dexamethasone, the jar was regassed for $20 \mathrm{~min}$ after removal of each time point's explants, and then sealed and returned to the rotating table in the incubator.

Immunohistochemistry. The explants, which had been placed in neutral buffered formalin at the end of the culture period, were embedded in parafin and $4 \mu \mathrm{m}$ thick sections were prepared. The monoclonal antibody (13-7-10) used to develop the Western blots (in vivo studies discussed above) failed to react with formalin fixed tissue. We therefore performed our immunohistochemistry using serial dilutions of a polyclonal rabbit anti-CYP3A3/4 antibody [38], which was a gift from Dr. Steven Wrighton, Eli Lilly Corp., Indianapolis, IN. We have previously characterized this antibody as selectively identifying CYP3A proteins in rat jejunal tissue sections using the identical immunohistochemical techniques [30]. Following a 20 -min incubation with the primary antibody, the sections were sequentially incubated, with intervening washes in phosphate-buffered saline (PBS), with the following reagents (Histostain-SP kit, Zymed Laboratories, South San Francisco. CA): biotinylated goat anti-rabbit IgG (H\&L) for $20 \mathrm{~min}$, horseradish peroxidase conjugated streptavidin for $15 \mathrm{~min}$, hydrogen peroxide/aminoethylcarbazole for $3.5 \mathrm{~min}$. All incubations were carried out at room temperature. Sections were then counterstained with hematoxylin. A single observer (W.O.D.), who was blinded to the culture conditions, assessed the intensity of the staining of each section. Serial dilutions of the primary antibody were used to study sections from each of the explants but the 1:750 
dilution appeared to give the widest range of staining intensities between treatments.

RNA isolation. RNA was isolated from the entire explants by the method of Chomczynski and Sacchi [34]. Having an estimated weight of $40 \mathrm{mg}$, each explant was placed in $400 \mu \mathrm{L}$ of denaturing solution [34], homogenized in a conical glass tissue grinder with ground glass pestle, and then stored at $-80^{\circ}$. At a convenient later time, the solution was thawed quickly at $65^{\circ}$ and processed according to the published protocol, adjusting reagent volumes proportionately as appropriate for the initial $400 \mu \mathrm{L}$ volume.

Polymerase chain reaction. The polymerase chain reaction has been shown to be capable of quantitating multiple RNA species present in low abundance in small amounts of tissue $[39,40]$. This appeared to be an ideal technique for application to jejunal explants where enterocytes represent a small proportion of the total cell population. cDNA was prepared from each RNA sample by incubating $1 \mu \mathrm{g}$ total RNA at $41^{\circ}$ for $1 \mathrm{hr}$ with $35 \mathrm{U}$ of reverse transcriptase (from avian myeloblastosis virus; Seikagaku America, St. Petersburg, FL) in a 50$\mu \mathrm{L}$ reaction mixture containing $50 \mathrm{mM}$ Tris$\mathrm{HCl}$ ( $\mathrm{pH} \mathrm{8.3),} 50 \mathrm{mM}$ potassium chloride, $10 \mathrm{mM}$ dithiothreitol, $13 \mu \mathrm{M}$ oligo (12-18) $\mathrm{dT}$, and $0.5 \mathrm{mM}$ each dATP, dTTP, dGTP, and dCTP.

The polymerase chain reaction (PCR) was performed on each explant cDNA preparation. We used as primers 30 -mer synthetic oligonucleotides recognizing characteristic regions of the cDNAs of CYP3A1 (sense primer, bases 1368-1398; anti-sense primer, bases $1618-1648$; [5]) or rat intestinal fatty acid binding protein (IFABP; sense primer, bases 4-34; anti-sense primer, bases 370-400; [41]). To make amplification of genomic DNA distinguishable should it occur, the primers were chosen so that the amplified segments spanned an intron. The polymerase chain reaction was carried out in a total volume of $50 \mu \mathrm{L}$ containing $10 \mu \mathrm{L}$ of an enterocyte cDNA preparation and the following final concentrations of reagents: $10 \mathrm{mM}$ Tris- $\mathrm{HCl}(\mathrm{pH} \mathrm{8.3)}$, $50 \mathrm{mM}$ potassium chloride, $1.6 \mathrm{mM}$ magnesium chloride, $2 \mathrm{mM}$ dithiothreitol, $0.01 \%$ gelatin, 3.5 to 4.5 U Thermus aquaticus (Taq) DNA polymerase (Beckman, Arlington Heights, IL), $2 \mu \mathrm{M}$ each oligonucleotide primer, and $0.1 \mathrm{mM}$ each dATP, dTTP, dGTP, and dCTP.

PCR was carried out in a DNA Thermal Cycler (Perkin-Elmer Cetus, Norwalk, CT/Emeryville, CA) at conditions of $\left(94^{\circ}\right.$ for $45 \mathrm{sec}, 72^{\circ}$ for $1 \mathrm{~min}$ $15 \mathrm{sec}) \times 34$ cycles for CYP3A1 or 22 cycles for IFABP, followed by a final extension step at $72^{\circ}$ for $10 \mathrm{~min}$. The products were subjected to electrophoresis in $1 \%$ agarose (Gibco BRL) $/ 2 \%$ NuSieve (FMC BioProducts, Rockland, ME) $/ 0.04 \mathrm{M}$ Tris-acetate, $0.001 \mathrm{M}$ EDTA, pH 8.0 (TAE) gels in TAE buffer and stained with ethidium bromide to visualize the amplified fragments of CYP3A1 or IFABP cDNA (280 and 396 bp in size, respectively). We have shown previously ([30] and unpublished data) that when cDNA prepared from rat enterocytes is subjected to amplification under these conditions, the fragments of cDNA amplified with the CYP3A1 (detectable only in induced rats) and IFABP primers have the exact nucleic acid sequence predicted by the published cDNA sequences $[5,41]$.

To determine conditions under which the intensity of ethidium staining of amplified bands reflected tissue concentrations of the target mRNAs, RNA prepared from a jejunal explant was serially diluted with RNA prepared from rat heart (a tissue that did not contain detectable CYP3A1 or IFABP mRNAs). The RNA mixtures were then reverse transcribed into cDNAs and subjected to PCR using synthetic oligonucleotide primers specific for CYP3A1 or IFABP cDNA. We found that under the PCR conditions described above, the band intensity on ethidium stained gels diminished appropriately as the concentration of specific mRNA decreased in the samples (Fig. 1). This result was easily reproduced for IFABP but less easily for CYP3A1 for which higher numbers of PCR cycles were required to visualize a band. Minute differences in the efficiency of amplification can result in significant increases or decreases in the quantity of amplified cDNA, and disparities can be expected to increase as cycle number increases. However, we found that our results became quite reproducible when reactions were run in parallel using a single stock solution ( $40 \mu \mathrm{L}$ ) that contained all reagents except the cDNA sample to be assayed. We have analyzed enterocyte RNA samples simultaneously by this PCR technique and on Northern blots probed with a CYP3A1specific 30-mer synthetic oligonucleotide under conditions reported to selectively identify CYP3A1 mRNA [5]. The relative staining intensity of PCR products on the ethidium stained gels essentially mirrors the relative intensities of the hybridization signals on the Northern blots (data not shown). Nonetheless, the results of our PCR analyses must be considered semiquantitative in the absence of internal standards for amplification efficiency. All PCR amplifications were repeated at least twice, and representative ethidium stained gels are shown.

\section{RESII,TS}

\section{Time course of induction of $C Y P 3 A$ in vivo}

We have shown previously that when rats are treated with dexamethasone for 2 days, there is induction of CYP3A protein and CYP3A1 mRNA in enterocytes $[30]$. To determine the time course of induction, we treated a group of rats with a single dose of dexamethasone and killed them at various times after treatment. Mature enterocytes were harvested and the microsomal fraction was prepared as described in Methods. We were unable to detect an increase in the microsomal content of CYP3A protein prior to $6 \mathrm{hr}$ after intraperitoneal treatment and the concentration appeared to peak by $18 \mathrm{hr}$ (Fig. 2). In rats given the identical dose of dexamethasone by oral gavage, the time course of induction of CYP3A protein appeared to be identical (data not shown).

CYP3A1 mRNA was undetectable in enterocytes from uninduced animals as we have reported previously [30]. CYP3A1 mRNA became detectable by our PCR technique (see Methods) within 3-6 hr after intraperitoneal injection of dexamethasone (Fig. 3, top panel). This is similar to the time course 


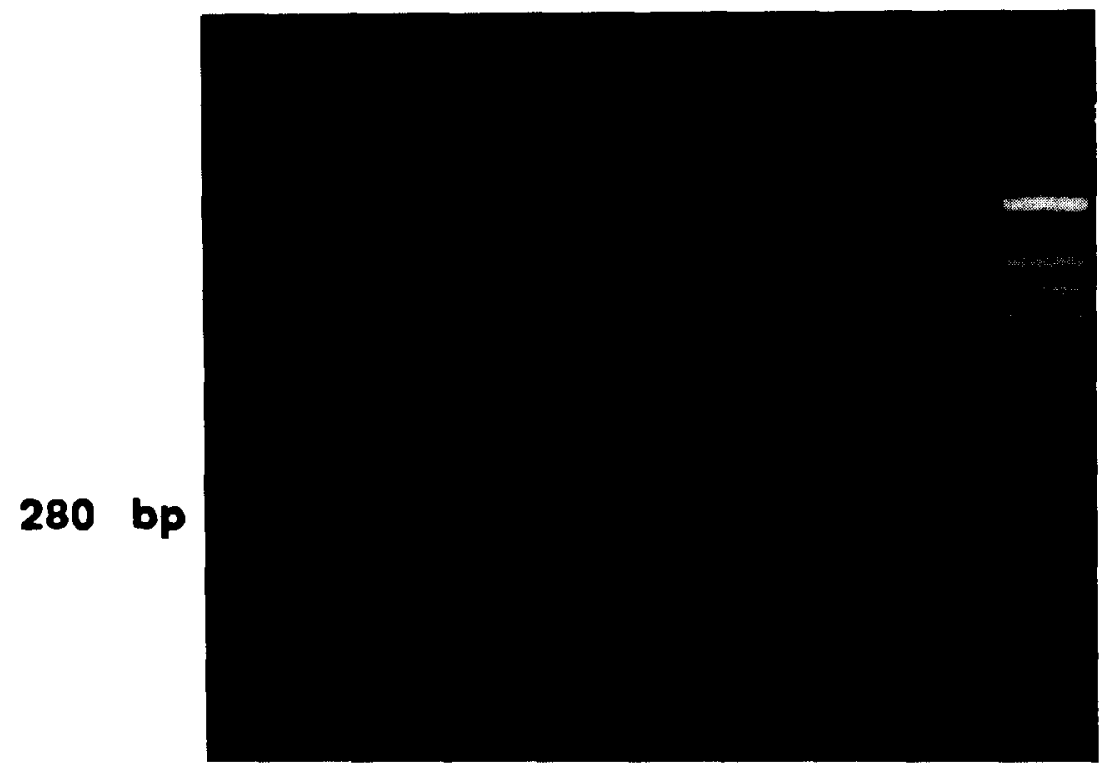

\section{$\begin{array}{llllllll}1: 1 & 1: 2 & 1: 4 & 1: 8 & 1: 16 & \text { Hrt Rgt MW }\end{array}$}

\section{6 bp}

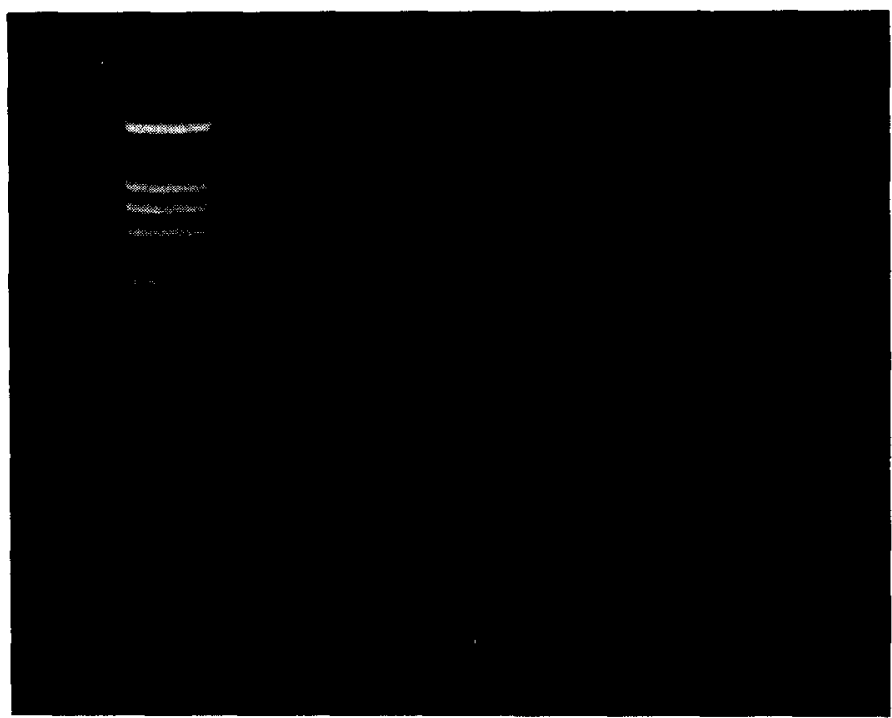

Rgt Std $1: 1 \quad 1: 2 \quad 1: 4 \quad 1: 8 \quad 1: 16 \mathrm{Hrt}$

Fig. 1. Quantitation of $C Y P 3 \wedge 1 \mathrm{mRN} \Lambda$ and intestinal fatty acid binding protein (IF $\Lambda \mathrm{BP}$ ) mRNA using the polymerase chain reaction (PCR). Total RNA obtained from enterocytes was diluted in the proportions indicated with RNA obtained from rat heart. The RNA mixtures were then reverse transcribed into cDNA and subjected to PCR using 30-mer synthetic oligonucleotide primers corresponding to characteristic regions of the CYP3A1 cDNA (top panel) or IFABP cDNA (bottom panel) as described in Methods. Abbreviations: Rgt, reagent mixture alone without cDNA added; Std or MW, molecular weight standards; and Hrt, heart cDNA.

of induction of CYP3A1 mRNA in the liver after an intraperitoneal dose of dexamethasone [42]. As a control, we determined the relative content of IFABP mRNA in each RNA sample using a semiquantitative PCR technique (see Methods). IFABP is abundant in villous tip enterocytes but is virtually absent from crypt cells or other cell types present in the small bowel wall [43], a distribution similar to that of CYP3A protein $[18,30]$. The concentration of IFABP should, therefore, reflect differences in the relative proportions of mature enterocytes obtained from each rat. In contrast to the induction of CYP3A1 mRNA in response to dexamethasone, the enterocyte content of IFABP 


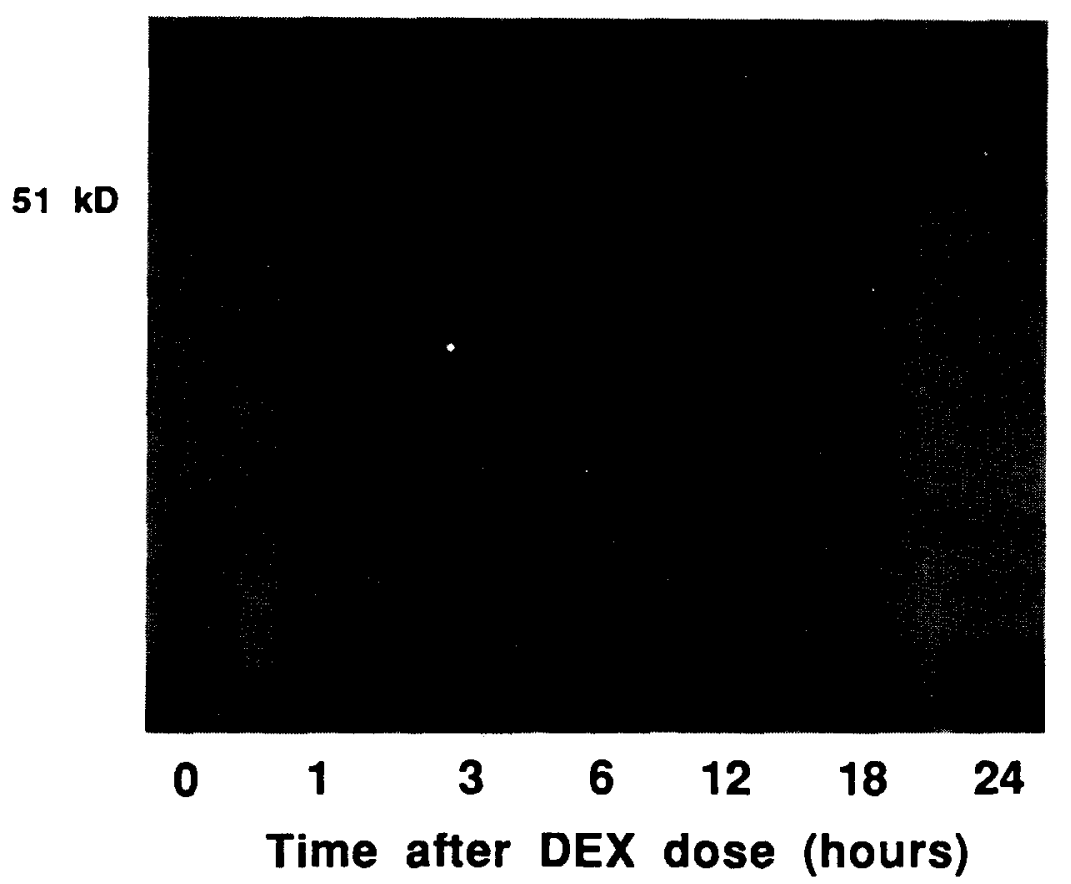

Fig. 2. Time course of induction of enterocyte CYP3A protein after a single intraperitoneal injection of dexamethasone (DEX). Adult fcmale rats received $80 \mathrm{mg} / \mathrm{kg} \mathrm{DEX}$ as a single intraperitoneal dose (time 0). Two rats were killed at each of the indicated time points and microsomes were prepared from the pooled jejunal enterocytes. The microsomal proteins $(5 \mu \mathrm{g} / \mathrm{lane})$ were separated on $10 \%$ polyacrylamide gels containing $0.1 \%$ sodium dodecyl sulfate (SDS) and then electrophoretically transferred to nitrocellulose sheets. The blots were incubated with a monoclonal antibody (13-7-10) that selectively recognizes CYP3A proteins. Antigen-antibody reaction was visualized using a peroxidase conjugated secondary antibody and 3,3'-diaminobenzidine tertrahydrochloride. This experiment was performed once.

mRNA did not increase, but instead appeared to transiently decrease, after treatment with dexamethasone (Fig. 3, bottom panel).

\section{Explant studies}

Considering the above in vivo data (Figs. 2 and 3 ), it would be necessary to maintain enterocytes ex vivo for at least $12 \mathrm{hr}$ in order to achieve our goal of developing an in vitro enterocyte model suitable for studying CYP3A1 regulation. We defined conditions (outlined in Methods) under which full thickness adult rat jejunal explants survived in culture for at least $18 \mathrm{hr}$. Although these explants showed dramatic morphologic changes over time in culture (Fig. 4), with loss of crypts by approximately $8 \mathrm{hr}$, viable appearing villous structures persisted to $21 \mathrm{hr}$. Enterocyte loss over time appeared to be disproportionately greater than loss of cells from the lamina propria. There was also a tendency toward enterocyte de-differentiation as judged by loss of cell height (Fig. 4) and contraction of the apical microvilli (Fig. 5).

To determine whether the jejunal explants remained responsive to dexamethasone, explants from nine rats were placed in medium containing either dexamethasone or vehicle alone (dimethyl sulfoxide) for $21 \mathrm{hr}$. The presence of dexamethasone in the medium did not appear to improve enterocyte differentiation as judged by electron and light microscopy (Figs. 5 and 6). However, immunohistochemical staining with anti-CYP3A3/4 indicated that enterocyte CYP3A protein had been induced in the presence of dexamethasone. In every case, an investigator blinded to the treatments judged the staining to be more intense in the explants exposed to dexamethasone than in control or $0 \mathrm{hr}$ explants from the same rat. There was also an increase in the number of enterocytes exhibiting immunoreactivity as compared to either control cultures or the $0 \mathrm{hr}$ tissue from the same rat (representative sections are shown in Fig. 6). In most instances, the control explants stained somewhat less intensely than did 0 -hr tissue.

We next examined whether CYP3A1 mRNA was also induced in explants by dexamethasone. In control explants from some rats, CYP3A1 mRNA became detectable by PCR between 12 and $16 \mathrm{hr}$ in culture, but then decreased, and was usually no longer detectable by $20 \mathrm{hr}$ (Fig. 7 , top panel). In dexamethasone-treated explants, CYP3A1 mRNA was detectable as early as $4 \mathrm{hr}$ in culture in some rats. The concentration of CYP3A1 mRNA then 


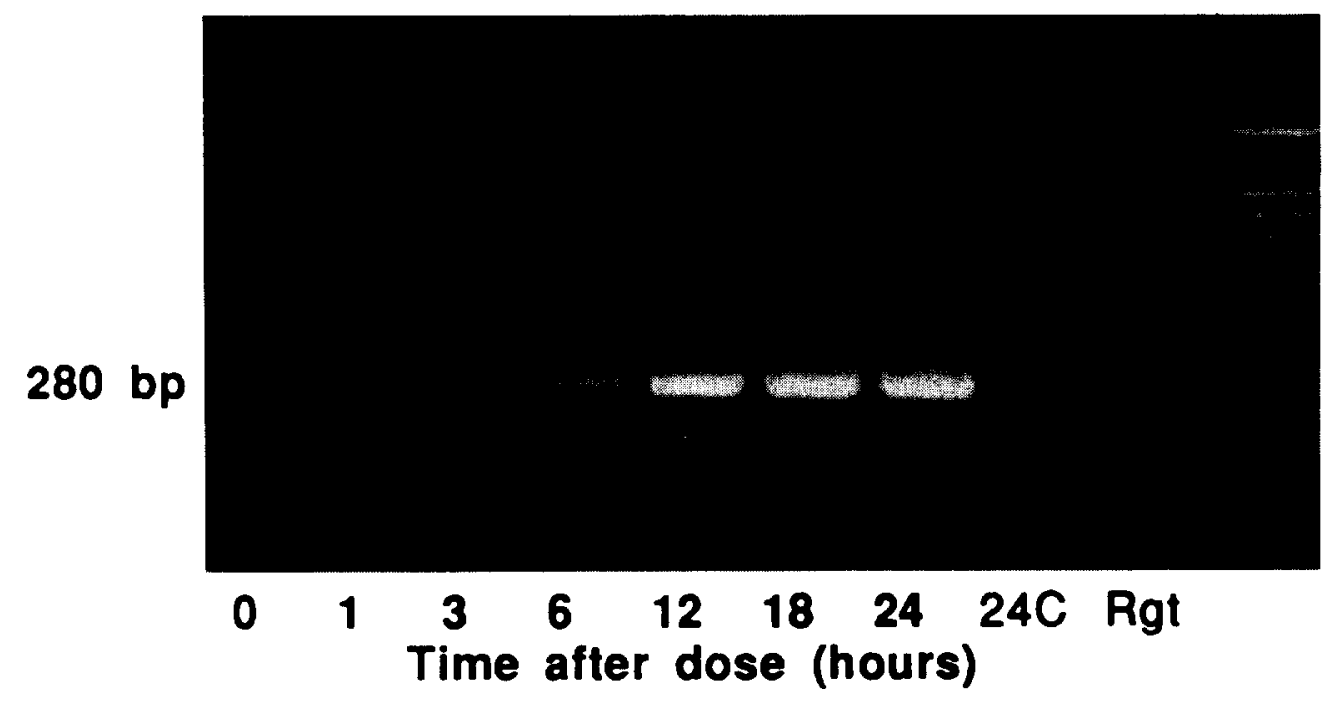

396 bp
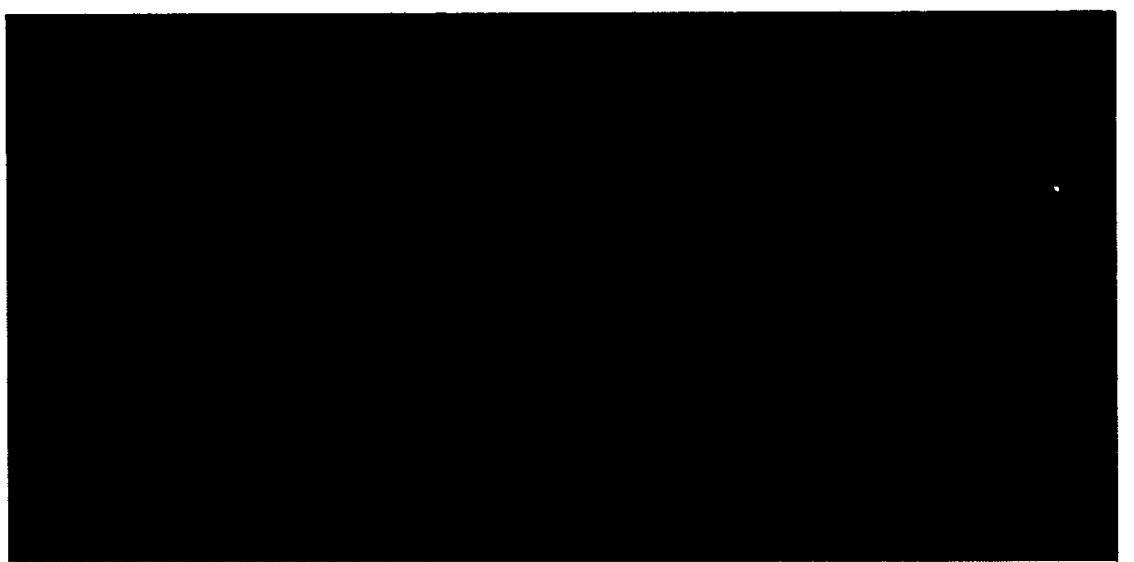

\section{$\begin{array}{llllllllll}0 & 1 & 3 & 6 & 12 & 18 & 24 & 24 \mathrm{C} & \mathrm{Rgt}\end{array}$ Time after dose (hours)}

Fig. 3. Time course of induction of enterocyte CYP3A1 mRNA after a single intraperitoneal injection of dexamethasone. Adult female rats received $80 \mathrm{mg} / \mathrm{kg}$ dexamethasone as a single intraperitoneal dose (time 0 ). Three rats were killed at each of the indicated time points, and total RNA was prepared from the pooled jejunal enterocytes. The RNA was reverse transcribed into cDNA and subjected to the semiquantitative PCR technique using oligonucleotide primers specific for CYP3A1 (top panel) and IFABP (bottom panel) cDNAs. The PCR reaction products were electrophoresed on $1 \%$ agarose $/ 2 \%$ NuSieve gels, stained with ethidium bromide, and the amplified bands were visualized by UV transillumination. The relative intensities of the ethidium stained bands on the gels reflect the relative concentrations of the target mRNAs present in the original RN $\Lambda$ samples (Fig. 1, Methods). Abbreviations: $24 \mathrm{C}$, control animal given intraperitoneal injection of vehicle (corn oil) alone; and Rgt, reagents alone without cDNA. This experiment was performed three times, with three rats per time point in each experiment.

progressively increased throughout the remaining time in culture (Fig. 7, top panel). Whenever CYP3A1 mRNA was at a detectable level, the concentration observed in dexamethasone-treated explants was always greater than that measured in the corresponding control explants. The content of IFABP mRNA (Fig. 7, bottom panel) progressively decreased over time in culture, consistent with the disproportionate loss of enterocytes as compared with other cell types within the explant (Fig. 4). The presence of dexamethasone in the medium had no consistent effect on the level of IFABP mRNA (Fig. 7 , bottom panel).

The above studies demonstrated that enterocytes in the explants remained responsive to dexamethasone. To further evaluate the usefulness of this model, we next exposed jejunal explants prepared from single rats to a variety of compounds believed to 


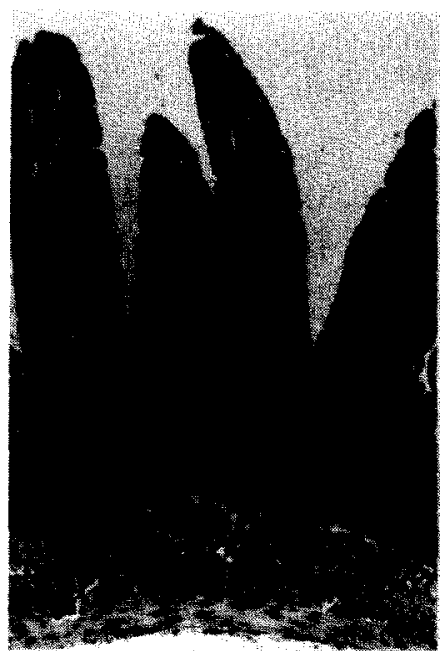

$\mathrm{Oh}$

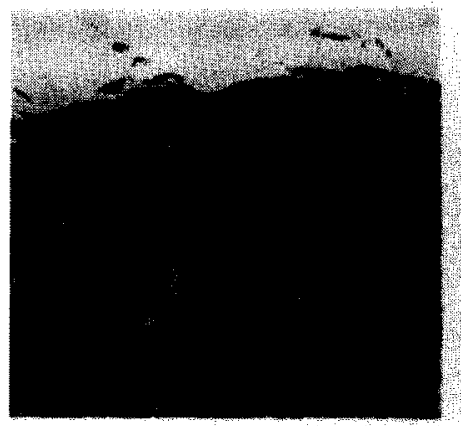

$4 \mathrm{~h}$

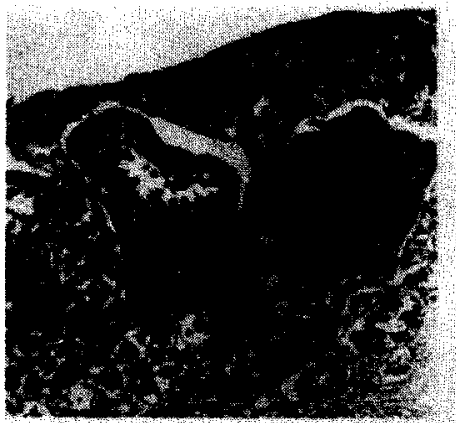

$16 \mathrm{~h}$

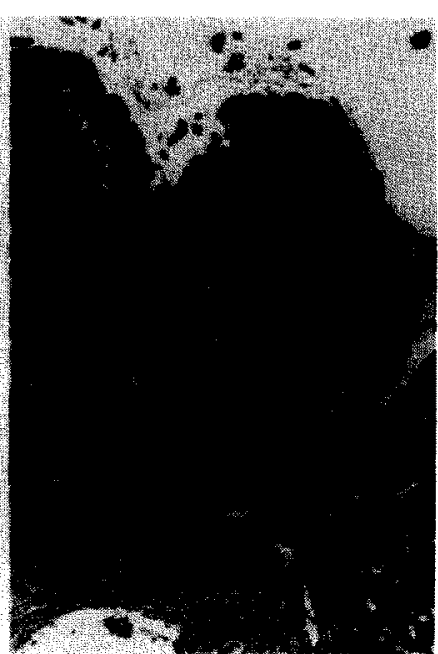

$1 \mathrm{~h}$

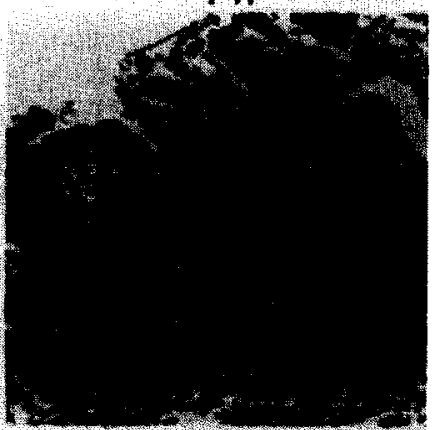

$12 \mathrm{~h}$

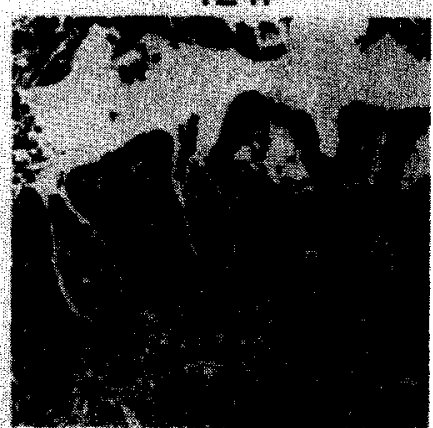

$21 \mathrm{~h}$

Fig. 4. Light microscopy of jejunal explants maintained in culture for up to $21 \mathrm{hr}$. Full thickness biopsies of rat jejunum were cultured under conditions described in Methods. Explants were removed from culture at the indicated time points, fixed in formalin, embedded in paraffin, sectioned, and stained with hematoxylin and eosin. Magnification: $\times 94$. This experiment was performed four timcs with explants obtained from four different rats.

induce CYP3A in liver $[7,10-13]$, in addition to dexamethasone. This experiment was performed in four different rats. The general viability and degree of maintenance of differentiation of enterocytes varied from culture to culture and from rat to rat, as judged by light microscopy (not shown). However, none of the compounds in the battery appeared to have a consistently beneficial or harmful effect on enterocyte viability or morphology.
The relative concentrations of CYP3A1 mRNA and of IFABP mRNA were determined in the explants treated with each potential inducer. Representative gels from electrophoresis of PCR products are shown in Fig. 8, top and bottom panels, respectively. An unequivocal increase in CYP3A1 mRNA (as compared with the level in the control explant from the same rat) was seen in the dexamethasone- or clotrimazole-treated explants 


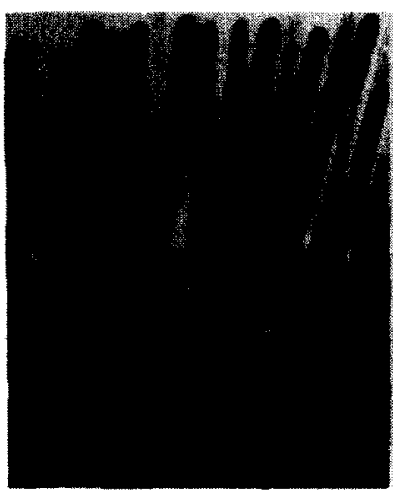

0 hour

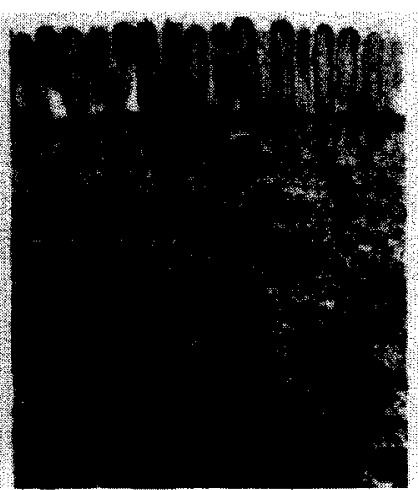

$18 \mathrm{~h}$ CONTROL

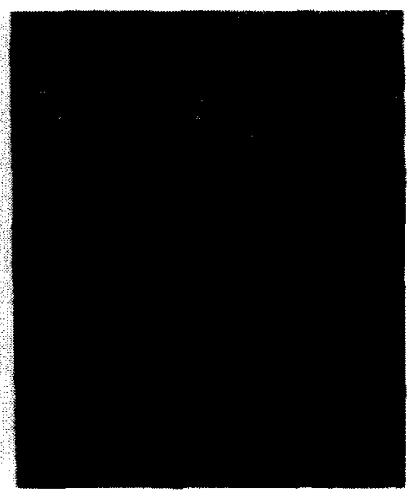

$18 \mathrm{~h}$ DEX

Fig. 5. Electron microscopy of enterocytes in the cultured explants. Jejunal explants were maintained in culture for $18 \mathrm{hr}$ and then fixed in $1 / 2$ strength Karnovsky's fixative, postfixed in osmium, embedded in epoxy resin, sectioned, and stained with uranyl magnesium acetate and with lead citrate. Magnification: $\times 21,000$. This was donc once on explants from one rat.

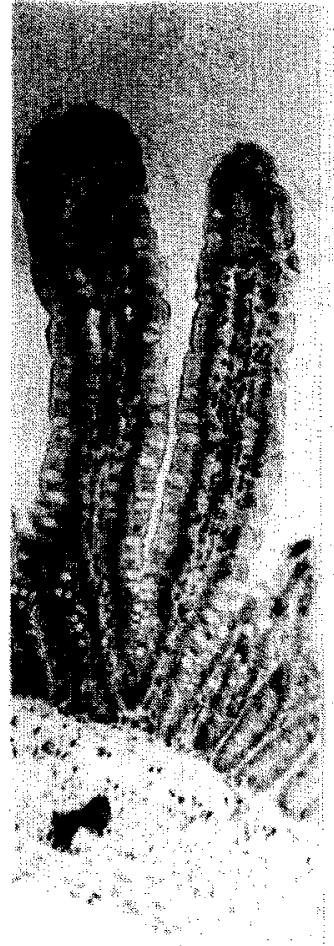

0 hour

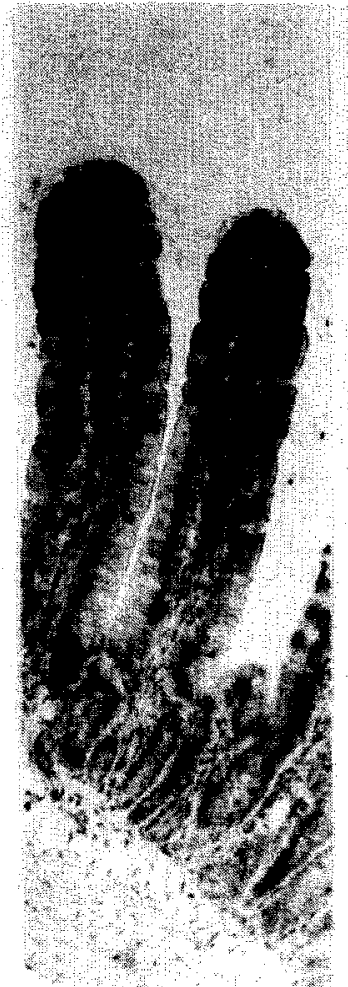

0 hour

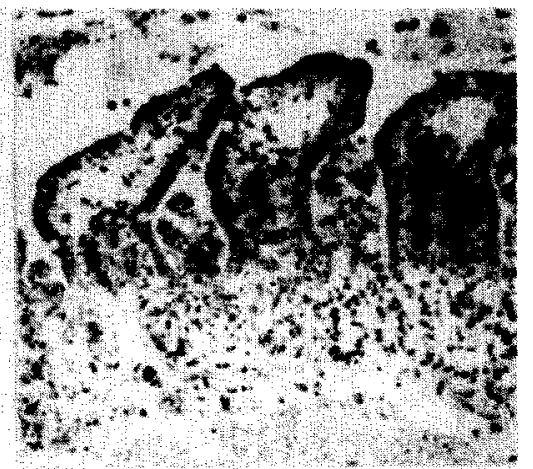

$21 \mathrm{~h} \mathrm{CONTROL}$

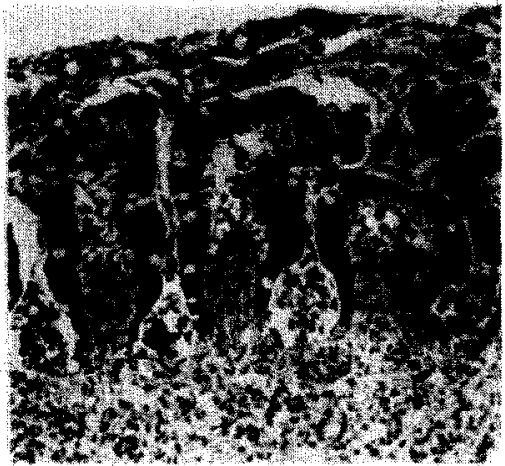

$21 \mathrm{~h}$ DEX

\section{pre-immune serum}

\section{anti-P450IIIA3/4 1:1500}

Fig. 6. Immunoreactive CYP3A protein in control and dexamethasone-treated explants. Jejunal explants were incubated in medium containing dexamethasone (DEX, $10^{-5} \mathrm{M}$ ) or vehicle (CONTROL; dimethyl sulfoxide) for $21 \mathrm{hr}$. The explants were then fixed in formalin, embedded in paraffin, sectioned, and incubated with various dilutions of anti-CYP3A3/4 IgG or pre-immune serum. Antibody reactivity (dark black) was visualized by sequential incubations with biotinylated secondary antibody, peroxidase conjugated streptavidin, and $\mathrm{H}_{2} \mathrm{O}_{2} /$ aminoethylcarbazole. Magnification: $\times 120$. This experiment was performed nine times with explants from nine different rats. 


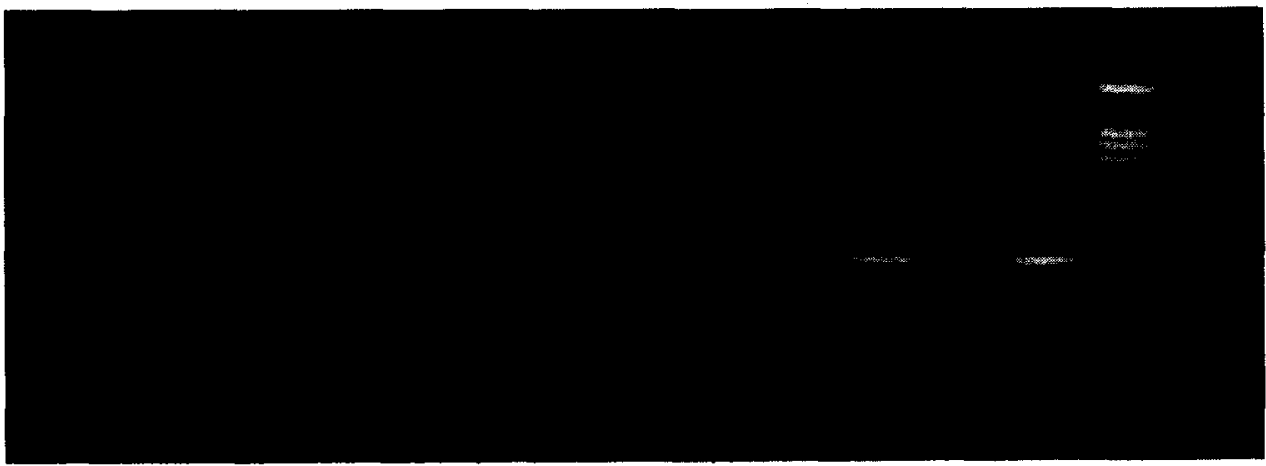

o
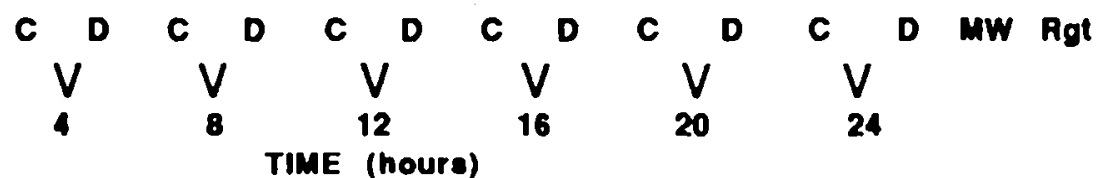

TIME (hours)

396 bp
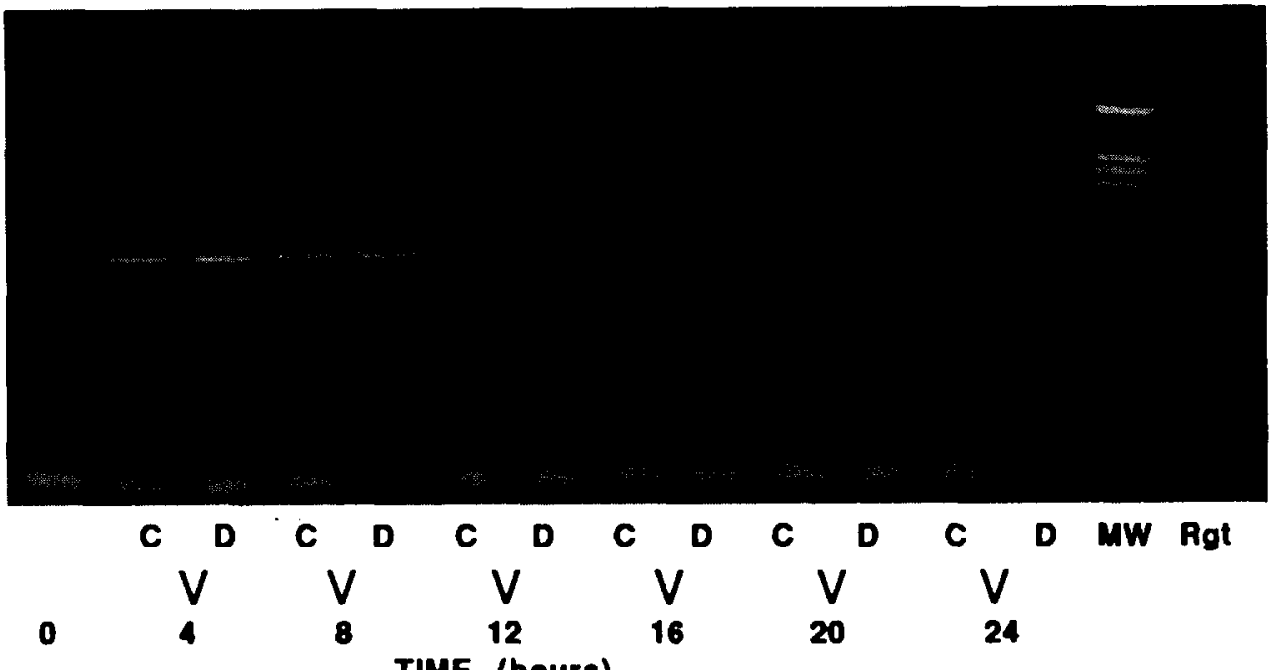

TIME (hours)

Fig. 7. Time course of induction of CYP3A1 mRNA (top panel) and IFABP mRNA (bottom panel) in cultured explants of jejunal mucosa. Explants were removed from culture at various times after the start of incubation in medium containing dexamethasone or vehicle alone (dimethyl sulfoxide). Total RNA was extracted from the entire explant, reverse transcribed into cDNA, and subjected to the semiquantitative PCR technique using oligonucleotide primers specific for CYP3Al (top) and IFABP (bottom) cDNAs as described in Methods. The reaction products were subjected to electrophoresis on $1 \%$ agarose $/ 2 \%$ NuSieve gels, stained with ethidium bromide, and the amplified bands were visualized by UV transillumination. Abbreviations: C, control (vehicle alone); D, dexamethasone treated; MW, molecular weight standards; and Rgt, reagents alone without cDNA. This experiment was performed twice with explants from two different rats.

prepared from each of the four rats. Induction was observed in three of the four explants treated with spironolactone or $\gamma$-chlordane, and in two of the four explants treated with ketoconazole or isosafrole. No induction of CYP3A1 mRNA was seen in any explants treated with phenobarbital, rifampicin, or troleandomycin as compared with controls. In contrast, there was little variation in the level of IFABP mRNA among the treatment groups, with none of the compounds having a consistent effect.

\section{DISCUSSION}

The goal of our studies was to develop an in vitro model suitable for studying regulation of CYP3A enzymes in enterocytes. Our in vivo studies suggested that it would be necessary to maintain enterocytes ex vivo for at least $12 \mathrm{hr}$ to study induction in response to dexamethasone. Isolated adult rat enterocytes in suspension culture remain viable for only several hours [44] and were therefore excluded 


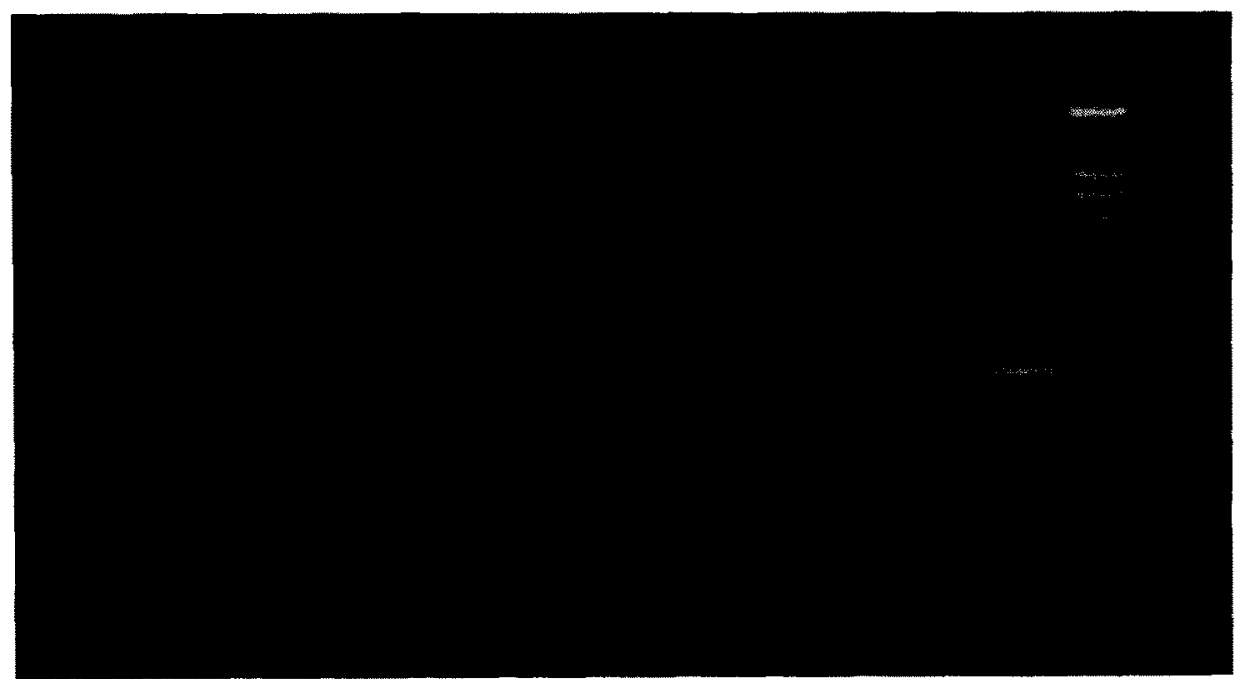

Ohr VEH CHL PB DEX SPN RIF TAO KET CLO ISO C1 C2 MW Rgt

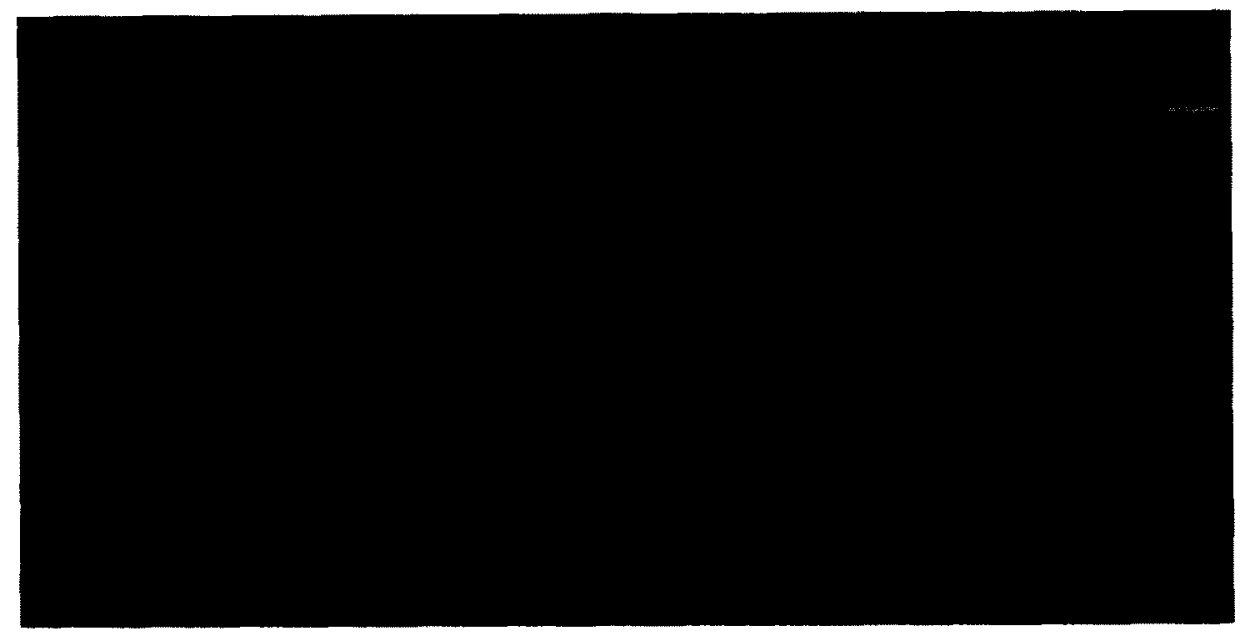

\section{onr VEH CHL PB DEX SPN RIF TAO KET CLO ISO C1 C2 Rgt MW}

Fig. 8. Induction of CYP3A1 mRNA in cultured jejunal explants exposed to various known inducers of hepatic CYP3A enzymes. Explants prepared from single rats were cultured for $18-21 \mathrm{hr}$ in the presence of each of the indicated compounds. Total RNA was extracted from the entire explant, reverse iranscribed into CDNA, and subjected to the semiquantitative PCR technique using oligonucleotide primers specific for CYP3A1 (top panel) and IFABP (bottom panel) cDNAs as described in Methods. The reaction products were subjected to electrophoresis on $1 \%$ agarose $/ 2 \%$ NuSieve gels, stained with ethidium bromide, and the amplified bands were visualized by UV transillumination. Abbreviations: VEH, vehicle (dimethyl sulfoxide); CHL, $\gamma$-chlordane; PB, phenobarbital; DEX, dexamethasone; SPN, spironolactone; RIF, rifampicin; TAO, troleandomycin; KET, ketoconazole; CLO, clotrimazole; ISO, isosafrole; $\mathrm{C} 1$, explant treated with pyrazole (an inducer of CYP2E1); C2, cDNA from jejunal scrapings from a dexamethasone-treated rat; $\mathrm{MW}$, molecular weight standards; and Rgt, reagents alone without cDNA. This experiment was performed four times with explants from four different rats.

from consideration. Epithelinid cells or cell lines can be derived from "outgrowths" from explanted fetal rat intestinal tissue that is maintained in culture for lengthy periods. These cells may develop certain differentiated structural features (e.g. microvilli [4446]) or functions (e.g. expression of alkaline phosphatase [45]). However, these cells lack certain antigenic characteristics of differentiated villous enterocytes [44] and retain some features of crypt or fetal enterocytes [46].

Several investigators have cultured full thickness biopsies of jejunum from several mammalian species including humans for greater than $24 \mathrm{hr}$ with preservation of morphological features. To our 
knowledge, however, there have been no previous reports of prolonged maintenance in culture of jejunal explants from adult rat which appear to be more difficult to maintain in culture than are jejunal explants obtained from other species [47]. Some investigators have had success culturing explants of fetal or suckling rat intestine. However, use of fetal tissue poses a problem when studying the regulation of CYP3A genes since these genes have complex developmental regulation, at least in liver [48].

We were able to define culture conditions under which adult rat jejunal explants maintained viable appearing villi for $21 \mathrm{hr}$, although the absolute number of viable enterocytes decreased with time in culture (Fig. 4). Total P450 levels were not evaluated in the explants, but we supplemented our medium with some of the elements and compounds that others have found to be important in maintaining P450 levels in primary cultures of rat hepatocytes: selenium [49]; 5-aminolevulinic acid [50,51]; and zinc [52]. The major disadvantage of explants is that enterocytes represent only a fraction of the total cells present (Fig. 4) and, therefore, CYP3A protein and mRNA are greatly diluted when the whole explant is processed. Indeed, it would be impossible to detect CYP3A protein or mRNA in the explants using standard immunoblot and Northern blot techniques, respectively. We therefore approached this problem by using immunohistochemistry and a semiquantitative PCR technique.

We found that dexamethasone treatment of explants resulted in induction of CYP3A protein in the villous enterocytes as judged by blinded interpretation of tissue sections incubated with antiCYP3A IgG (Fig. 6). Dexamethasone also resulted in a time-dependent induction of CYP3A1 mRNA (Fig. 7, top panel) that was essentially indistinguishable from our observations in enterocytes in vivo (Fig. 3, top panel). Since even our highly sensitive PCR technique could not detect CYP3A1 mRNA in control enterocytes, it seems likely that induction of enterocyte CYP3A1 mRNA by dexamethasone involves transcriptional activation, as is the case in liver [42]. However, weak induction of CYP3A1 mRNA was also detectable in explants at early time points in the control medium (Fig. 7 , top panel), suggesting transient transcriptional activation of the $C Y P 3 A 1$ gene. Therefore, we cannot entirely exclude the possibility that accumulation of CYP3A1 mRNA in the dexamethasone-treated explants was the result of mRNA stabilization rather than transcriptional activation of the corresponding gene. Post-transcriptional induction of other P450s has been shown to occur in hepatocytes in primary culture in the presence of dexamethasone [53]. However, dexamethasone did not cause an accumulation of all enterocyte mRNAs in our explants since it appeared to have no consistent effect on the concentration of IFABP mRNA in the explants (bottom panels of Figs. 7 and 8).

Finally, we treated cultured jejunal explants with a battery of compounds that appear to induce CYP3A in liver. We found unequivocal induction of CYP3A1 mRNA in each explant treated with dexamethasone or clotrimazole. Our data suggest that spironolactone, $\gamma$-chlordane, ketoconazole, and isosafrole are also capable of inducing CYP3A1 mRNA in the explants. In contrast, rifampicin, troleandomycin, and phenobarbital did not induce CYP3A1 mRNA in any of the explants. The lack of response to rifampicin is not surprising since this compound is not an inducer of CYP3A enzymes in rat liver (in distinction to rabbit and human liver) $[10,54]$. Troleandomycin is an inducer of CYP3A protein and mRNA in rat liver but not in primary rat hepatocytes in culture [12]. It remains to be determined whether troleandomycin is an inducer of CYP3A enzymes in enterocytes in vivo. The absence of induction of enterocyte CYP3A1 mRNA in the explants treated with phenobarbital may reflect the relatively low concentration $\left(10^{-5} \mathrm{M}\right)$ of phenobarbital used. Higher concentrations $\left(2 \times 10^{-3} \mathrm{M}\right)$ of phenobarbital have been used to demonstrate induction of CYP3A protein and CYP3A1 mRNA in cutured hepatocytes [17].

In summary, explant culture of jejunal biopsies appears to be a promising ex vivo system to study the regulation of $C Y P 3 A$ genes in enterocytes. We have been able to demonstrate dexamethasone induction of CYP3A1 mRNA and CYP3A protein in explants and our results generally mirror the effects of dexamethasone in vivo. Our preliminary studies with other potential inducers suggest that enterocyte CYP3A1 mRNA is inducible by other compounds known to induce this mRNA in hepatocytes. We believe that the techniques we present here can be readily adapted to studying regulation of other drug-metabolizing enzymes in enterocytes. CYP1 and CYP2 family members, for example, are also present and inducible in rat enterocytes [55]. It should be possible to use PCR to simultaneously quantitate the mRNAs corresponding to these and to many other drugmetabolizing enzymes in explants. Finally, it should be possible to adapt our culture and assay techniques to obtain similar information from duodenal biopsies that are routinely obtained from patients during endoscopic procedures.

Acknowledgements-This research was supported by the NIH (GM 38149, P.B.W.). Drs. Watkins and Kolars are recipients of V.A. Career Development Awards.

\section{REFERENCES}

1. Watkins PB, Role of cytochromes P450 in drug metabolism and hepatotoxicity. Semin Liver Dis 10: 235-250, 1990.

2. Guengerich FP, Characterization of human microsomal cytochrome P-450 enzymes. Annu Rev Pharmacol Toxicol 29: 241-264, 1989.

3. Gonzalez FJ, Molecular genetics of the P-450 superfamily. Pharmacol Ther 45: 1-38, 1990.

4. Nebert DW, Nelson DR, Coon MJ, Estabrook RW, Feyereisen R, Fujii-Kuriyama Y, Gonzalez FJ, Guengerich FP, Gunsalus IC, Johnson EF, Loper JC, Sato R, Waterman MR and Waxman DJ, The P450 superfamily: Update on new sequences, gene mapping, and recommended nomenclature. DNA Cell Biol 10: $1-14,1991$.

5. Gonzalez FJ, Song B-J and Hardwick JP, Pregnenolone 16 $\alpha$-carbonitrile-inducible P.450 gene family: Gene conversion and differential regulation. Mol Cell Biol 6: 2969-2976, 1986. 
6. Halpert JR, Multiplicity of steroid-inducible cytochromes P-450 in rat liver microsomes. Arch Biochem Biophys 263: 59-68, 1988. [Published erratum appears in Arch Biochem Biophys 265: 226, 1988.]

7. Hostetler KA, Wrighton SA, Kremers $P$ and Guzelian PS, Immunochemical evidence for multiple steroidinducible hepatic cytochromes $\mathrm{P}-450$ in the rat. Biochem J 245: 27-33, 1987.

8. Kolars JC, Murray SA, Peters KM and Watkins PB, Differential regulation of liver P-450III cytochromes in choline-deficient rats: Implications for the erythromycin breath test as a parameter of liver function. Hepatology 12: $1371-1378,1990$.

9. Heuman DM, Gallagher EJ, Barwick JL, Elshourbagy NA and Guzelian PS, Immunochemical evidence for induction of a common form of hepatic cytochrome P. 450 in rats treated with pregnenolone-16 $\alpha$-carbonitrile or other steroidal or non-steroidal agents. Mol Pharmacol 21: 753-760, 1982.

10. Wrighton SA, Schuetz EG, Watkins PB, Maurel P, Barwick J, Bailey BS, Hartle HT, Young B and Guzelian P, Demonstration in multiple species of inducible hepatic cytochromes $\mathbf{P}-\mathbf{4 5 0}$ and their mRNAs related to the glucocorticoid-inducible cytochrome $P$ 450 of the rat. Mol Pharmacol 28: 312-321, 1985.

11. Hostetler KA, Wrighton SA, Molowa DT, Thomas PE, Levin $W$ and Guzelian PS, Coinduction of multiple hepatic cytochrome $P-450$ proteins and their mRNAs in rats treated with imidazole antimycotic agents. $\mathrm{Mol}$ Pharmacol 35: 279-285, 1989.

12. Watkins PB, Wrighton SA, Schuetz EG, Maurel P and Guzelian PS, Macrolide antibiotics inhibit the degradation of the glucocorticoid-responsive cytochrome P-450p in rat hepatocytes in vivo and in primary monolayer culture. J Biol Chem 261: 6264 6271,1986

13. Pichard L, Fabre I, Fabre G, Domergue J, Saint Aubert B, Mourad G and Maurel P, Cyclosporin A drug interactions: Screening for inducers and inhibitors of cytochrome P450 (cyclosporin A oxidase) in primary cultures of human hepatocytes and in liver microsomes. Drug Metab Dispos 18: 595-606, 1990.

14. Schuetz EG and Guzelian PS, Induction of cytochrome $P-450$ by glucocorticoids in rat liver. II. Evidence that glucocorticoids regulate induction of cytochrome $P-450$ by a nonclassical receptor mechanism. $J$ Biol Chem 259: 2007-2012, 1984.

15. Schuetz EG, Hazelton GA, Hall J, Watkins PB, Klaassen $C D$ and Guzelian PS, Induction of digitoxigenin monodigitoxoside UDP-glucuronosyltransferase activity by glucocorticoids and other inducers of cytochrome $\mathrm{P}-450 \mathrm{p}$ in primary monolayer cultures of adult rat hepatocytes and in human liver. $J$ Biol Chem 261: 8270-8275, 1986.

16. Schuetz EG, Li D, Omiecinski CJ, Muller-Eberhard $U$, Kleinman HK, Elswick $B$ and Guzelian PS, Regulation of gene expression in adult rat hepatocytes cultured on a basement membrane matrix. $J$ Cell Physiol 134: 309-323, 1988.

17. Schuetz EG, Wrighton SA, Safe SH and Guzelian PS, Regulation of cytochrome P-450p by phenobarbital and phenobarbital-like inducers in adult rat hepatocytes in primary monolayer culture and in vivo. Biochemistry 25: 1124-1133, 1986.

18. Watkins PB, Wrighton SA, Schuetz EG, Molowa DT and Guzelian PS, Identification of glucocorticoidinducible cytochromes $\mathrm{P}-450$ in the intestinal mucosa of rats and man. J Clin Invest 80: 1029-1036, 1987.

19. Kolars JC, Schmiedlin-Ren P, Schuetz JD, Fang C and Watkins $\mathrm{PB}$, Identification of rifampicin-inducible P450IIIA4 (CYP3A4) in human small bowel enterocytes. $J$ Clin Invest 90: 1871-1878, 1992.

20. Kolars JC, Stetson PL, Rush BD, Ruwart MJ,
Schmiedlin-Ren P, Duell EA, Voorhees JJ and Watkins $\mathrm{PB}$, Cyclosporine metabolism by P450IIIA in rat enterocytes-Another determinant of oral bioavailability? Transplantation 53: 596-602, 1992.

21. Kolars JC, Awni WM, Merion RM and Watkins PB, First-pass metabolism of cyclosporin by the gut. Lancet 338: 1488-1490, 1991.

22. Lucey MR, Kolars JC, Merion RM, Campbell DA, Aldrich $M$ and Watkins $P B$, Cyclosporin toxicity at therapeutic blood levels and cytochrome P-450IIIA. Lancet 335: 11-15, 1990.

23. Hebert MF, Roberts JP, Prueksaritanont $T$ and Benet LZ, Bioavailability of cyclosporine with concomitant rifampin administration is markedly less than predicted by hepatic enzyme induction. Clin Pharmacol Ther 52: 453-457, 1992.

24. Guengerich FP, Martin MV, Beaune PH, Kremers $P$, Wolff $T$ and Waxman DJ, Characterization of rat and human liver microsomal cytochrome P-450 forms involved in nifedipine oxidation, a prototype for genetic polymorphism in oxidative drug metabolism. J Biol Chem 261: 5051-5060, 1986.

25. Kronbach T, Fischer V and Meyer UA, Cyclosporine metabolism in human liver: Identification of a cytochrome P-450III gene family as the major cyclosporine-metabolizing enzyme explains interactions of cyclosporine with other drugs. Clin Pharmacol Ther 43: $630-635,1988$.

26. Shimada $T$ and Guengerich FP, Evidence for cytochrome $\mathrm{P}-450_{\mathrm{NF}}$, the nifedipine oxidase, being the principal enzyme involved in the bioactivation of aflatoxins in human liver. Proc Natl Acad Sci USA 86: 462-465, 1989.

27. Weiser MM, Intestinal epithelial cell surface membrane glycoprotein synthesis. I. An indicator of cellular differentiation. I Biol Chem 248: 2536-2541, 1973.

28. Bonkovsky HL, Hauri H-P, Marti U, Gasser R and Meyer UA, Cytochrome P450 of small intestinal epithelial cells. Immunochemical characterization of the increase in cytochrome P450 caused by phenobarbital. Gastroenterology 88: 458-467, 1985.

29. Schacterle GR and Pollack RL, A simplified method for the quantitative assay of small amounts of protein in biologic material. Anal Biochem 51: 654-655, 1973.

30. Kolars JC, Schmiedlin-Ren P, Dobbins WO III, Schuetz J, Wrighton SA and Watkins PB, Heterogeneity of cytochrome P-450IIIA expression in rat gut epithelia. Gastroenterology 102: 1186-1198, 1992.

31. Beaune P, Kremers P, Letawe-Goujon F and Gielen JE, Monoclonal antibodies against human liver cytochrome P-450. Biochem Pharmacol 34: 3547-3552, 1985.

32. Chirgwin JM, Przybyla AE, MacDonald RJ and Rutter WJ, Isolation of biologically active ribonucleic acid from sources enriched in ribonuclease. Biochemistry 18: 5294-5299, 1979.

33. Glisin V, Crkvenjakov $R$ and Byus $C$, Ribonucleic acid isolation by cesium chloride centrifugation. Biochemistry 13: 2633-2637, 1974.

34. Chomczynski $P$ and Sacchi N, Single-step method of RNA isolation by acid guanidinium thiocyanatephenol-chloroform extraction. Anal Biochem 162: 156$159,1987$.

35. Browning TH and Trier JS, Organ culture of mucosal biopsies of human small intestine. $J$ Clin Invest 48: 1423-1432, 1969.

36. Autrup $H$, Stoner GD, Jackson $F$, Harris $C C$, Shamsuddin AKM, Barrett LA and Trump BF, Explant culture of rat colon: A model system for studying metabolism of chemical carcinogens. In Vitro 14: 868$877,1978$.

37. Schuetz EG, Wrighton SA, Barwick JL and Guzelian PS, Induction of cytochrome P-450 by glucocorticoids 
in rat liver. I. Evidence that glucocorticoids and pregnenolone-16 $\alpha$-carbonitrile regulate de novo synthesis of a common form of cytochrome P-450 in cultures of adult rat hepatocytes and in the liver in vivo. J Biol Chem 259: 1999-2006, 1984.

38. Wrighton SA, Brian WR, Sari M-A, Iwasaki $M$, Guengerich FP, Raucy JL, Molowa DT and Vandenbranden $M$, Studies on the expression and metabolic capabilities of human liver cytochrome P450IIIA5 (HLp3). Mol Pharmacol 38: 207-213, 1990.

39. Becker-Andre $M$ and Hahlbrock K, Absolute mRNA quantification using the polymerase chain reaction (PCR). A novel approach by a PCR aided transcript titration assay (PATTY). Nucleic Acids Res 17: 94379446, 1989.

40. Wang AM, Doyle MV and Mark DF, Quantitation of mRNA by the polymerase chain reaction. Proc Natl Acad Sci USA 86: 9717-9721, 1989.

41. Alpers DH, Strauss AW, Ockner RK, Bass NM and Gordon JI, Cloning of a cDNA encoding rat intestinal fatty acid binding protein. Proc Natl Acad Sci USA 81: 313-317, 1984.

42. Simmons DL, McQuiddy $P$ and Kasper CB, Induction of the hepatic mixed-function oxidase system by synthetic glucocorticoids. Transcriptional and posttranscriptional regulation. J Biol Chem 262: 326-332, 1987.

43. Shields HM, Bates ML, Bass NM, Best CJ, Alpers DH and Ockner RK, Light microscopic immunocytochemical localization of hepatic and intestinal types of fatty acid-binding proteins in rat small intestine. $J$ Lipid Res 27: 549-557, 1986.

44. Quaroni A, Wands J, Trelstad RL and Isselbacher KJ, Epithelioid cell cultures from rat small intestine. Characterization by morphologic and immunologic criteria. J Cell Biol 80: 248-265, 1979.

45. Hahn U, Schuppan D, Hahn EG, Merker H-J and Riecken E-O, Intestinal cells produce basement membrane proteins in vitro. Gut 28 (suppl 1): 143$151,1987$.
46. Quaroni A, Development of fetal rat intestine in organ and monolayer culture. $J$ Cell Biol 100: 1611-1622, 1985.

47. Haffen K, Kedinger $M$ and Grenier JF, Etude de la survie en culture organotypique de la muqueuse intestinale de trois especes de Mammiferes. $C R$ Seances Soc Biol Fil 167: 1973-1977, 1973.

48. Waxman DJ, Dannan GA and Guengerich FP, Regulation of rat hepatic cytochrome P-450: Agedependent expression, hormonal imprinting, and xenobiotic inducibility of sex-specific isoenzymes. Biochemstry 24: 4409-4417, 1985 .

49. Newman S and Guzelian PS, Stimulation of de novo synthesis of cytochrome $\mathrm{P}-450$ by phenobarbital in primary nonproliferating cultures of adult rat hepatocytes. Proc Natl Acad Sci USA 79: 2922-2926. 1982.

50. Paine $A J$ and Hockin $L J$, Nutrient imbalance causes the loss of cytochrome P-450 in liver cell culture: Formulation of culture media which maintain cytochrome $\mathrm{P}-450$ at in vivo concentrations. Biochem Pharmacol 29: 3215-3218, 1980.

51. Guzelian PS and Bissell DM, Effect of cobalt on synthesis of heme and cytochrome P-450 in the liver. Studies of adult rat hepatocytes in primary monolayer culture and in vivo. $J$ Biol Chem 251: 4421-4427, 1976.

52. Guzelian PS, O'Connor L, Fernandez S, Chan W, Giampietro $P$ and Desnick $R$, Rapid loss of $\delta$ aminolevulinic acid dehydratase activity in primary cultures of adult rat hepatocytes: A new model of zinc deficiency. Life Sci 31: 1111-1116, 1982.

53. Silver G, Reid LM and Krauter KS, Dexamethasonemediated regulation of 3-methylcholanthrene-induced cytochrome P450d mRNA accumulation in primary rat hepatocyte cultures. J Biol Chem 265: 3134-3138, 1990.

54. Watkins PB, Murray SA, Winkelman LG, Heuman DM, Wrighton SA and Guzelian PS, Erythromycin breath test as an assay of glucocorticoid-inducible liver cytochromes P-450. J Clin Invest 83: 688-697, 1989.

55. Kaminsky LS and Fasco MJ, Small intestinal cytochromes P450. Crit Rev Toxicol 21: 407-422, 1992. 